\title{
III. Reply to the "Apology for the Postscript on the Refractions" in No. 24 of The Quarterly Journal of Science
}

James Ivory M.A.F.R.S.

To cite this article: James Ivory M.A.F.R.S. (1822) III. Reply to the "Apology for the Postscript on the Refractions" in No. 24 of The Quarterly Journal of Science, Philosophical Magazine Series 1, 59:285, 16-21, DOI: $10.1080 / 14786442208652667$

To link to this article: http://dx.doi.org/10.1080/14786442208652667

电 Published online: 27 Jul 2009.

Submit your article to this journal $₫$

Џll Article views: 2

Q View related articles $\sqsubset$ 
found, that when the tar has been nearly evaporated, this yellow farina will begin to pass off.

It remains for me to propose a name for the white concrete substance which has been described in this paper: and, unless a more appropriate term should be suggested by others, I would propose to call it Naphthaline.

III. Reply to the "Apology for the Postscript on the Refractions" in No. 24 of The Quarterly Journal of Science. By JAMES IVORY, M.A. F.R.S.

\section{To Dr. Tilloch.}

SIR, - I have to request the favour of your inserting the following observations in reply to an article that has appeared in the last Quarterly Journal of Science. I shall take no notice of what is merely personal; but it would not be right to allow a writing so entirely calculated to mislead, to go before the public without making some attempt to enable it to judge of the merits of the case.

Although drawn up with some art and great apparent confidence, the article, in fact, leaves the observations I wrote on the new method of computing the refractions just in the same predicament they would be, if no such apology had been published.

I found that the series, or the development of the density of the air in terms of the refraction, was not sufficiently convergent to be of use. Does the author contradict this? He dós not: on the contrary he allows it, by flying off to a different and more laborious method of computation, which has nothing to do with the construction of the table in the Nautical Almanack, the only point I proposed to examine, and the only point about which it is worth while to bestow a thought.

The method he employs consists in considering the variable quantities in the several stages of their increase, and computing their successive values by repeated operations. It is a method resorted to when all others fail. Recourse is had to it here from the want of convergency of the series first contemplated, and by which his table is constructed, with the hope, no doubt, of rescuing his mode of calculation from the reproach of a total failure.

The methods of calculation proposed by Dr. Young are not new, although he may be the only mathematician that has applied them to the problem of the refractions. They are the first that occurred in the progress of the integral calculus. Would it 
not therefore have been better to refer to some work of undoubted reputation with the public, than to have attempted to explain them by calculations, of which it cannot be said that any one result is accurate? But in this manner his readers would have been better able to judge of his consistency and fairness of arguing, when they found him affirming gravely that there is no want of convergency of the series, at the very time the default of convergency obliges him to employ subsidiary expedients.

By taking the whole values of the variable quantities at two intervals, he seems to have considerably diminished the error arising from the want of convergency of the series. But, how many intervals must be taken in order to exhaust it completely? We thus fall upon the same discussions agitated from the origin of the science. At any rate it appears necessary that he push his calculations up to the nark of truth, at least in some one instance, before the methods he recommends can be fairly compared with those usually followed. But, however this be, it must not be forgotten that the method of calculating by intervals, has nothing to do with the construction of the table in the Nautical Almanack.

The formula used in the construction of the table contains four terms; and the horizontal refraction in the table, is immediately found by solving the proper equation. But when we take a case of real theory; that is, one proceeding upon a given hypothesis of density, by which means the coefficients of the series are taken out of the clutches of the computer, and are derived solely fiom the nature of the case; then six terms of the series, not to say four, are totally inadequate for finding the refraction with the requisite exactness. What is the reason of this? Is it not that, in the one case, the coefficients are so adjusted as to bring out the desired result; while, in the other case, the expectation of the computer is balked, because the modelling of the series is placed out of his power?

The coefficient of the first of the four terms is unavoidably determined by the uature of the case, or by the differential equation: the other three are empirical. Nor will much be abated from this, if it be allowed that some assistance has been derived from a small exertion of the reasoning faculty in fixing the form of the coefficients, while their quantity is obtained entirely by a tentative method aiming at given results. Nothing in the apology is contrary to what is here advanced. It is admitted that the formula is partly empirical, and we are referred to Fuler's Lunar Theory, as a parallel case. This instance is not very much to the point: for although the immeusity of the calculations, and the impracticability of performing them, made it necessary to seek from observation what could not be found by theory, yet

Vol. 59. No. 285. Jan. 1822. 
this must be considered as an imperfection and a blemish, if we may be allowed to use such words in speaking of a matter that so highly concerned the benefit of mankind. A few years ago, the Academy of Sciences proposed, for their prize-question, the Construetion of Lunar Tables by Theory alone, the fortunate competitors being M. Damoiseau and MM. Plana and Carlini. But, in the case of the refractions, we are desired to hold a retrograde course, and are required to re-compute by an empirical formula the very same numbers already calculated by theory.

The author of the Apology misquotes my words, and slurs over the question of the identity of his table with that of the French. It is not enough to say that they agree in all ordinary cases; for there is no difference between them in the mean refractions. This is a fact of which any one may satisfy himself by reducing both tables to bar. 30 , or both to bar. 29.93 , the mean temperature being the same in both cases. The slight differences that occur will generally be found less than the discrepancies arising in solving over again the equations of the new method.

As there is no particular hypothesis of density adopted, the theory of the formula, if there be any, can be nothing but the general consideration that the density of the air, being a function of the refraction, may be developed in a series of the powers of that quantity. It therefore became necessary to prove not only that the series converged in every possible hypothesis of density, but that it converged so fast as to permit the rejecting of all the terms after the four first. Now this is not only not done, but it is not true.

But, it may be asked, how then does it happen that the formula represents the French mean refractions so exactly? Now even this question may, I think, be answered in a satisfactory manner. By adopting the hypothesis of a density decreasing uniformly, we obtain an exact solution of the problem of refractions in the form of an equation containing the two first powers of the quantity sought. The rules of Bradley, Mayer, \&c. are all equivalent to the solution of a quadratic equation*. In their original form these rules can be applied only to compute the refractions at altitudes greater than $12^{\circ}$, or $14^{\circ}$; nearer the horizon they diverge from the truth. But if we relax from the strictly theoretical quantities, and determine the coefficients so as to represent the refractions at the horizon and at $45^{\circ}$ from the zenith, we obtain empirical formulæ that apply with considerable exactness even at low altitudes. Now if to the two terms of such a formula, two more be added, so as to have three terms with indeterminate coefficients, a great latitude of calculation

$$
\text { * Kramp, Ref. Ast., p. } 164 .
$$


will be acquired; and we may so determine the arbitrary quantities as greatly to diminish, and even almost to annihilate, the differences between the formula and observation, or between the formula and a given table of refractions. And this, 1 conceive, is a just and sufficient account of the coincidence between the tables of mean refraction in the Nautical Almanack and the Connaissance des Tems.

Suppose Dr. Young's formnla with literal coefficients was given to each of two computers, one in London and one in Paris; and they were directed to determine the numerical values, so as to represent the French table: it is by no means, clear that both would hit upon. the same numbers for the coefficients. It will not appear improbable to any one who has attended to the variety of numerical formulæ for calonlating the refractions*, that the result of such an experiment might be, two different formulre equally representing the prescribed table.

It will not, I hope, be inferred from any thing that has been said, that an empirical table of refractions is supposed to be of little value. It can indeed have no value at all unless it have a proper foundation of its own, which can only be the case when it is constructed from an extensive series of observations made in every diversity of circumstances. A table, however constructed, that is a mere copy of another, can have no authority which the original does not possess.

Upon the method of allowing for the variations of the barometer and thermometer, I made no observatious. It would be very difficult to prove in a strict manner either its correctness or incorrectness. Besides, it is independent of the new method for the mean refractions, which alone I undertook to examine. This independence of the two methods arises from the empiricism of the formula. For had the formula been theoretical, the coefficients, instead of being numbers, wonld have contained the quantities that vary with the state of the atmosphere; and one expression would have served, as ought to be the case, both for the mean refractions, and the mutations they undergo by the barometrical and thermometrical changes. The safest way to deal with this part of the table, is to compare it with some other table of at least equal authority. That of Dr. Briukley will answer best, because the two tables agree in having the same mean horizontal refraction. Thus, for bar. 30 and ther. $50^{\circ}$, the horizontal refraction is,

$$
\begin{array}{lllllll}
\text { Dr. Brinkley } & \ldots & \ldots & \ldots & 33^{\prime} 50^{\prime \prime} \\
\text { N. A. } & \text {. } & \ldots & \ldots & \ldots & 33 & 51 .
\end{array}
$$

Now, suppose a change of temperature of $18^{\circ}$, and compute

* De Lambre's Astronomy, vol. i. chap. 13.

C 2 


\section{Reply to the "Apology for the Postscript on the Refractions."}

the refractions for the zenith-distances $90^{\circ}$ and $89^{\circ}$, bar. 30 and ther. $32^{\circ}$ :

\begin{tabular}{llllllll} 
& & \multicolumn{3}{c}{ Z. D. $90^{\circ}$} & \multicolumn{3}{c}{ Z. D. $89^{\circ}$} \\
Dr. Brinkley & $\ldots$ & $36^{\prime}$ & $51^{\prime \prime}$ & & $26^{\prime}$ & $2^{\prime \prime}$ \\
N. A. & $\ldots$ & $\ldots$ & 36 & 17 & & 25. & 50 \\
& & & $\frac{36}{2}$ & & \\
Diff. & $\ldots$ & $\ldots$ & & 34 & & & 12
\end{tabular}

And such differences must always occur, unless some general principles be adopted, or some general mode of solution can be found out.

Allow me, sir, before I conclude, to say a word about the "Concessions" in your Mag. for last November. It is not easy to state distinctly what is conceded and what is withheld. The balance seems to be poised with a very even hand, between the concessions to be made, and the tone of authority to be kept up. If $\mathrm{F}$ might presume to give an opinion, I would say that the only error I am now charged with, relates to ny number 000419 which he malies 00416 ; amounting to $T \frac{8}{0.00}$ of an inch, if we speali absolutely; or, relat:vely as my antagonist takes it, to $\frac{1}{T^{4}}$ of the existing quantity. There is some refinement in this way of reckoning; for the less the quantity, the greater the error. I ain sure there is nobody who has attended to the controversy, but will allow that the chance of an error in his nnmber is greatly in my favour ; but the whole difference is so very little, and he has already descanted upon it so amply, that it would be a pity to add another word upon the subject. Besides, we shall soon have a table of surpassing accuracy; when he bas spent his money in hiring a host of computers to complete his lucubrations.

I have some consolation, sir, in thinking that the discussions, in your work, on the subject of the refractions, will be foms not altogether unimportant or uninteresting to the astronomer. I allude to the general view of the problem in your Magazine for May last, and to the formulæ for the mean refractions in the same, and the following, number; to the observations made on the hypothesis of Cassini ; and particularly to the remarks on Mayer's formula in the Magazine for November. Since writing that article I have looked into the Fundamenta Astronomice of Professor Bessel, who is the only author I have met with that does justice to the astrononer of Göttingen. In speaking of the correction for the thermoneter, he thus expresses himself, $\mu .26$,

"Ceterum in hoc quoque capite non æquales solum, verum etiam posteriores astronomos antecessit Tohias Mayer, in refractionis formula rectius adbibens thermometri correetionem; utrum observationes an theoria eum huc perduxerint latet: sed confitendum est, correctionem illam postea inutilem atque falsam judicatan cjugque auctorem vituperatum esse quod eam caleulis inserucrit. 
inseruerit. Etsi subtilis theoretica thermometri correctionis determinatio non prorsus congruit cum Mayeri hrijus rei tractande ratione: tamen, si eam recipissent astronomi, maximam partem evitassent errortm, quos gignet refractio, aeris densitati in observatoris loco aut refrangendi facultati tota proportionalis posita."

It now remains that I thank you, sir, for your attention to $\mathrm{my}$ communications, and that I express my regret you were troubled with the short letter in your last Number : but I was not then aware that a public man, upon a public question, would descend to personal abuse, even if he found himself without good arguments to urge in his defence.

Jan. 7, 1822 .

I am, $\operatorname{sir}, \& c$.

JAMES IVORY.

\section{On Short-hand Writing. By Henry Upington, Esq.}

\section{To Dr. Tillach.}

Blair's Hill, Cork, Nov, 5, 1821.

Bear Sir, - Grve me leave to occupy your attention for a short time, upon a subject which, although in itself not a branch of philosophy or literature, must, if successfully cultivated, be acknowledged as a valuable acquisition by every one who is desirous of occasionally taking down the heads of a disconrse, or who devotes a considerable portion of his life either to the transcribing of the works of others, or to original composition.

You will very easily perceive, sir, by this prefatory observation, that I should willingly realize, as far as in my power, the suggestion of Mr. Locke, by putting every gentleman in possession of the most expeditious method of short-writing compatible with perspicuity and ordinary muscular execution. This is most certainly my intention; and if I should be so fortunate as to enable the literary part of my countrymen to save, in the course of every day, even one or two hours which must otherwise be devoted to manual drudgery, I shall feel myself most amply recompensed.

The prominent objection of the most intelligent persons with whom I have conversed, to the cultivation of short-hand as generally practined, is in my opinion extremely rational. They insist that even years are necessary to execute with sufficient ease the various crabbed angles, and consequent difficult combinations depcudent upon the four different positions, left, right, perpendicular and horizontal, as thus ${ } \mid 1-$ : and that until an absolutely automatical command of these be obtaiued, even the intellectual Note-taker or Reporter who uses short-liand is 